\title{
CALVYN: INSTITUSIE, KONFESSIE EN KATEGISMUS
}

\author{
Dr. H. W. Simpson, Dep. Hoof Latyn, PU vir CHO
}

Det Dominus nobis in caelestis suce sapientiae mysteriis cum vero pietatis profectu versari in gloriam suam et aedificationem nostram. Amen.

(Mag die Here ons dit gun om ons met waaragtige vordering in godsvrug met die geheimenisse van sy hemelse wysheld besig te hou tot sy heerlikheid en tot ons opbou. Amen)

\section{Inleidend}

Geagte Voorsitter, ek wil u bedank vir die geleentheid om hier voor $u$ op te tree. U sal geredelik begryp dat ek dit om besondere redes wat ek hierin later sal noem, met groot nederigheid doen. Dit is egter vir my ' $n$ behoefte om juis aan die mense wat my in meer as een opsig in die geleentheid gestel het om my met hierdie heerlike werk besig te hou, dank te betuig. Ek verwys natuurlik in besonder na die Deputate van die Calvyn Jubileum Boekefonds wat nie alleen die middele voorsien het om die eerste uitgawe van die Institutio se vertaling die lig te laat sien nie, maar ook 'n aansienlike bydrae gemaak het om die versameling van die oorspronklike uitgawes van Calvyn se werke moontlik te maak. U kan u voorstel watter voorreg dit is om uit enige van die agt eerste uitgawes van hierdie opus magnum van Calvyn te kan werk. Ek het meer as ander rede om die Gereformeerde Kerk dankbaar te wees vir lewensonderhoud, opvoeding en vorming. Ook aan professore van die Teologiese Skool is ek besonderlik dank verskuldig vir stille inspirasie en ophelderende gesprekke in 'n gees van pragtige samewerking wat net groot belofte vir die toekoms inhou. Mag ek die hoop uitspreek dat die werk wat voor u lê blyke sal gee van my waardering en dat die samewerking in die toekoms nog nouer sal wees.

Geagte Voorsitter, $u$ sal ook begryp dat $u$ uitnodiging enigsins vreemd is. 'n Mens sou trouens verwag dat 'n teoloog voor die G.T.V. sou optree met die tema hierbo. Dit is daarom ook nodig dat ek ten aanvange my taak as filoloog nie teenoor die teoloog nie, maar eerder in samewerking omskrywe. Die gebed hierbo waarmee Calvyn elke lesing ingelei het is ' $n$ ideale voorbeeld om dit te illustreer. Dit is die filoloog se taak om te vertaal, om die semantiese draagwydte, die herkoms en uiteindelike (in casu Christelike) bestemming van woorde soos Dominus, sapientiae, mysteriis, pietatis, gloriam en aedificationem te deurvors en vir die teoloog te ontsluit. Daarom moet die filoloog kennis dra van die possessor-servus-verhouding, die juridies kultuur-historiese ontwikkeling van die begrip en die uiteindelike proses van absorbering van die woord Dominus in 'n Christelike milieu. Calvyn gee trouens self daarvan blyke dat hy hierdie besondere woord in diepte eers verstaan het na die uitgawe van die Institutio in 1536. Dit is naamlik opsigtelik dat hy die woord twee keer gebruik as attribute van Koning Frans 1 in die aanhef tot die Praefatio van hierdie werk. In die uitgawes wat 
hierop volg is die woord weggelaat en gebruik Calvyn dit slegs om die Here te beskrywe!

Aan die ander kant is dit die teoloog se taak om verskeie aspekte van die gebed te evalueer - dogmaties, skeurend, bindend, stigtend, reg of verkeerd, ens. en sy bevindinge te integreer in die totaliteit van sy wetenskap. Natuurlik sou 'n teoloog/filoloog die beste in staat wees daartoe om so 'n taak in sy volle omvang te verrig. U kan dus die afleiding maak dat my uiteensetting hier in 'n sekere sin gebrekkig is - omdat dit eensydig vanuit die gesigspunt van die filoloog benader is ${ }^{1}$. Ek hoop egter dat die materiaal hier ontsluit is sodat die teoloog dit kan interpreteer en integreer in die teologie.

\section{Probleemstelling}

Dr. Coetzee het my aanvanklik gevra om een of meer fasette in verband met die vertaling van die Institutio Christianae Religionis van Calvyn toe te lig. Dit geld beide die editio princeps van 1536 as die editio ultima van 1559 met die vertaling waarvan ons tans besig is. Die voltooiing hiervan word beoog vir 1984 wanneer die volgende Suid-Afrikaanse Calvynnavorsingskongres in Potchefstroom gehou sal word. By die geleentheid sal Calvyn se 475ste geboortejaar herdenk word en dit is ook vir die CJBF 'n jubileumjaar.

Ek wil u egter nie vermoei met al die teorieë in verband met vertalingstegnieke en die wyse waarop linguistieke en generatiewe transformasioneel grammatikale navorsingsresultate hierby geintegreer word nie. Ek wil bloot terloops opmerk dat my ervaring daarvan is dat vertaling ' $n$ hoogs individuele aktiwiteit is wat hom nie altyd gemaklik deur teorieë in 'n hoek laat dryf nie. Ek het daarom gemeen dat dit baie meer produktief is om 'n voorbeeld van so ' $n$ vertaling vir $u$ kommentaar en oordeel aan $u$ voor te lê. Die vertaling is gedoen na aanleiding van Santandreanus se 1597 uitgawe van die traktate van Calvyn en is een van die werke wat onlangs oorsee bekom is.

Ek wil my egter nie daarmee verontskuldig of losmaak van die versoek nie. Die tema spruit trouens uit die probleme wat uit die vertaling van die Institutio voortgespruit het. ,Onderwysing' lê immers ten grondslag van sowel die Institutio as die Catechismus tot so 'n mate so dat daar nie alleen by Luther nie, maar ook ten aanvange by Calvyn nie onderskeid tussen die twee gemaak is nie. Diehl het trouens bewys dat Calvyn in sy Institusie (1536) baie sterk geleun het op die Kategismus van Luther en selfs die sisteem getuig daarvan dat Luther se werk hierin sterk nagevolg is.

Dit is voorts opvallend dat die titel van Calvyn se 1538-uitgawe van die Instruction Kategismus en Institusie sonder onderskeid parallel aan mekaar verbind: CATECHISMUS seu christianae religionis INSTITUTIO. Met die oog op die vertaling is dit natuurlik van kardinale belang om tussen hierdie begrippe te onderskei omdat daarmee ook die verskil tussen Calvinus doctor en Calvinus polemicus aangedui word.

Terwyl die Belydenisskrifte van ons kerke tans in die proses van hersiening is, is dit nie maar net 'n stukkie intellektuele gimnastiek om hierdie ooreenkomste en verskille uit te wys nie. Daar 
kan weinig twyfel daaroor bestaan dat beide Olevianus en Ursinus 'n sterk klap weg gehad het van Calvyn se Kategismus en dat hierdie invloed positief neerslag gevind het by die skepping van die Heidelberger. Beide hierdie Kategismusvormers het in elk geval op een of ander stadium aan die voete van Calvyn gesit (Bouwmeester, Zacharias Ursinus, p. 10; Caspar Olevianus, p. 30).

Die insluiting van Confessio by die tema lyk op die oog af onvanpas. Daar is immers 'n duidelike onderliggende didaktiese struktuur in die Institusie en die Kategismus merkbaar wat tog nie die geval is met die Confessio nie. Afgesien hiervan is die outentisiteit van Calvyn se outeurskap hiervan nie bo alle twyfel bewys nie - Farel se aandeel hierin word trouens baie hoër aangeslaan as die van Calvyn! (Van 't Veer, p. 23 e.v.). As die noue verbintenis tussen Catechismus en Confessio wat beide in die 1537 (1536?)uitgawe en in die 1538-uitgawe deur dieselfde praefatio voorafgegaan word, in aanmerking geneem word, is die insluiting daarvan nie sinneloos nie. Die titel in die 1537-uitgawe lui: Instruction et Confession de foy. Confessio en Catechismus is hierin dus direk aan mekaar verbind. Dit regverdig per se 'n ondersoek.

Verdere motivering vir die ondersoek van hierdie tema spruit uit die ervaring met die editio princeps en die sowat vyfkeer meer omvattende editio ultima van 1559. Gewoonlik word hierdie invloede op die uitbreiding van die Institusie in besonder beklemtoon (Wendel, Sources, p. 79 e.v.), maar die invloed vanuit die Institusie op ander werke van Calvyn gewoonlik agterweë gelaat. Ons onderwerp is daarom ook in hierdie opsig van belang.

In hierdie ondersoek kan ons egter nie aan veel meer as blote formele aspekte aandag gee nie. Ons beplan om kortliks elk van die aspekte van die tema toe te lig, dit vergelykend te ondersoek en die ooreenkomste en verskille daarin aan te dui in besonder ten opsigte van Institusie en Kategismus.

\section{Die Institutio Christianae Religionis}

Imbert de la Tour meen dat die som van die Calvinisme ingesluit is in die Institusie. Hy noem dit 'n Oevre capitale, oevre préférée de Calvin qui passa sa vie à la réviser, à la manier, comme $\grave{a}$ l'enrichir ${ }^{2}$. In sy aanvanklike stelling is hy natuurlik verkeerd Calvyn is immers nie Calvinisme nie en Calvinisme ook nie Calvyn nie! Sy stelling dra egter besondere betekenis omdat dit die omvattende aard van die Institusie beskrywe. Die editio ultima is trouens die presipitaat van enersyds 'n progressiewe verrykende polemiek en andersyds van Calvyn se persoonlike rypwordingsproses. In sy finale vorm is dit ' $n$ werk sonder gelyke in die Reformatoriese milieu omdat Calvyn gepoog het om daarin ' $n$ volledige samevatting van die doctrina christiana te gee. In die reeks van agt uitgawes wat Calvyn daaraan gegee het om die werk in sy finale vorm af te rond is die eerste en tweede uitgawes hier vir ons bespreking van belang.

\subsection{Die editio princeps -1536}

Calvyn se doelstelling met die skrywe van sy eersteling Institusie word beskrywe in die titel daarvan en in die praefatio aan Koning 
Frans 1 (1515-1547) nader toegelig. Die volledige titel van die werk is: Christianae Religionis Institutio totam fere pietatis summam et quidquid est in doctrina salutis cognitu necessarium complectens. Omnibus pietatis studiosis lectu dignissimum opus ac recens editum. Praefatio ad Chritianissimum Regem Franciae qua hic ei liber pro conffesione fidei offertur. Dit is in Maart 1536 in Basel uitgegee deur Thomas Platterus en Balthasar Lasius. (Verwysings volg hierdie oorspronklike uitgawe).

Uit hierdie titel kan ons die volgende aflei:

* dat dit bedoel is as 'n summa pietatis - dit is 'n samevatting van die godsvrug of 'n compendium praeceptorum doctrinae christianae;

** dat dit die oordrag van kennis van die doctrina salutis - die heilsleer - beoog;

*** dat dit as 'n confessio fidei-'n geloofsbelydenis - bedoel is.

In die praefatio - dikwels verkeerdelik die epistola nuncupatoria genoem - omlyn die skrywer sy doelstellinge met die werk meer uitdruklik:

* Sy aanvanklike (CUM huic operi manum PRIMUM admoverem) doelstelling was slegs om enkele grondbeginsels oor te dra (rudimenta quaedam tradere) om mense wat nog belangstelling in die godsdiens het na die ware godsvrug ad veram pietatem) te lei;

** Die vervolging van die Protestante het hierin egter 'n verandering gebring. Vervolgingsdruk noodsaak 'n confessio fidei sodat die koning uit hulle geloofsbelydenis kon aflei wat die doctrina salutis is waarvoor die Protestante bereid is om te sterf.

Inhoudelik en formeel kan hierdie doelstellings dus gereduseer word tot twee fasette:

* n.a.v. tradere - 'n didaktiese (of onderwysings-) opset;

** n.a.v. confessio - 'n apologetiese opset.

Op die klassieke institusiewese wil ek hier nie ingaan nie. Genoegsaam om te sê dat hierdie twee fasette ook kenmerkend van die cerste Christelike Institusie was. Dit is nie vir ons sonder betekenis nie aangesien dit algemeen bekend is dat daar vir al Calvyn se werke gewoonlik 'n letterkundige model uit sy onmiddellike milieu gesoek word. In die geval van sy eersteling Institusie vind kommentatore dit in die algemeen in Erasmus se Institutio principis christianae (1516) of Guillaume Budé se La Instruction du Prince wat in 1547 gepubliseer, maar reeds in 1524 geskrywe is. Dat daar in hierdie werke 'n didaktiese opset aanwesig is, kan geredelik toegegee word, maar dit spreek tog duidelik dat daarin geen behoefte aan ' $n$ confessio fidei was met die doel wat dit in die Institusie van Calvyn gehad het nie. Om Calvyn se doelstellings te herlei tot 'n blote Instruction doen sy werk 'n onreg aan en ontneem dit die konfessionele inhoud. Daarbenewens misken dit die lang ontwikkelingsgeskiedenis van die Christelike institusiewese sedert die ontstaan daarvan in $303 \mathrm{n}$.C. en die feit dat Calvyn ook literêre erfgenaam van die Vroeg Christelike tradisie was. Lactantius 
se Divinae Institutiones (CSEL IX en MPL 6 en 7) toon tewens 'n duidelik parallelle doelstelling naamlik om die doctrina vera oor te dra en vanuit die ware leer beswaar aan te teken teen die iniquitas van die owerheid. Die praefatio in Calvyn se Institusie gee duidelik daarvan blyke dat die confessio fidei eweneens gerig is op die onreg wat die Protestante aangedoen word.

Die medium waardeur die onderwysing in die Institusie gedra word is die disputatio - 'n woord wat herhaaldelik in die werk voorkom. Dit is in besonder die geval in bykans elke prooemium van afsonderlike hoofstukke. So bv. in hoofstuk 2: iam satis ex proxima DISPUTATIONE intellegi potest.... (vgl. OC 1.56); Hoofstuk 3: ex his quae hactenus DISPUTATA sunt.... (gl. OC 1.81); Hoofstuk 5: poterat superior de sacramentis DISPUTATIO apud dociles et sobrios hoc obtinere... (vgl. OC 1.141); hoofstuk 6: sed nos planiorem eius DISPUTATIONEM (nam leviter supra a nobis attacta est) in hunc locum reiecimus.... (vgl. OC 1.195).

Formeel is die Institutio dus 'n denkbeeldige debat - 'n disputatio wat van al die middels van die rhetorica en in besonder van die argumentum en ratio gebruik maak. Argument en rede gee aan die skrywer die geleentheid om by die inhoud van die teenstander se opvatting betrokke te raak en hom suis armis te beveg. Die woord ergo konkludeer 'n argumentum en lewer bewys daarvan dat Calvyn ook van die retoriese (contra filosofiese) sillogisme gebruik gemaak het. Dit is egter 'n tema met sulke wye implikasies dat ons dit noodwendig agterweë moet laat.

Die teikengebied (simpliciores) en die inhoud (vrye gebruik van die geskrifte van die Kerkvaders en selfs heidense outeurs) dui daarop dat Calvyn in die Institusie noue aansluiting gaan soek het by die klassieke diatribe - 'keine Literaturgattung, sondern eine besondere Art mũndlicher Propaganda, die sich aan die breiteste Massen wendet' (Capelle en Marrou in RAC 3.993). Wenland karakteriseer hierdie vorm van kommunikasie as ,ein äussert lebendiger, oft durch Anrede der Hörer oder durch Einführung fingierter Gegner oder Personificationen dialogisch gestalter Vortrag, eine vorwiegend polemische Tendenz, ein überreicher Schmuck von Versen der Lieblingsdichter, ein ebenso reichlicher Gebrauch von Apothegmen und Anekdoten, eine Vorliebe für witzige Pointen und Antithesen, für stets treffende, nicht immer gewahlte Vergleiche, kurz ein Vortrag, in allem berechnet, die Menge $\mathrm{zu}$ packen und zu fessin, ein Stil der durch Satzlösung und Bevorzugung der Parataxe scheinbar auf alle Mittel kunstvoller Rede versichtet und der doch, wie in Gebrauch vulgärer Ausdrücke unter scheinbarer Kunstlösigkeit das höchste Raffinement und rhetorische Berechnung birgt.' (Wendland, p. 441). Met inagneming van Calvyn se oorspronklikheid kan na my mening aangetoon word dat die Institusie aan 'n groot hoeveelheid van hierdie eienskappe beantwoord.

Afgesien daarvan dat Calvyn klaarblyklik aansluiting vind by die klassieke Christelike tradisie was die De libero arbitrio DIATPIBH sive collatio per Desiderium Erasmum Roterodamum, (Basel, Froben, Sept. 1524) ongetwyfeld ook tot sy beskikking. Hy het hom trouens van die begin van sy skrywersaktiwiteit as 'n vurige student van die 
Rotterdammer bewys deur in sy kommentaar op die De clementia van Seneca die kommentaar van Erasmus as die kern van sy polemiek te neem.

Maar dit is ook duidelik dat Calvyn so 'n literêre vorm nie klakkeloos oorneem nie. Hy stempel ook daarop eie individualiteit met snydende satire, ironie en sarkasme (in besonder in hoofstuk 6) af. In hierdie gespreksituasie neem Calvyn positief stelling in teenoor al die strominge waarmee die Reformasie diametraal bots. Geleentheid vir 'n neutrale via media of aurea mediocritos kom by hom nie voor nie. Daarom is Battles na my mening die kluts skoon kwyt wanneer hy Calvyn se posisie as 'n via media ,between the Scylla of aberrant Romanism and the Charybdis of the radical tendencies of his time" beskrywe (in Neuser, Calvinus ecclesiae doctor, p. 85 e.v.).

Terloops moet opgemerk word dat die talle aanhalings en verwysings na die Scriptura sancta, die Kerkvaders en selfs klassieke heidense skrywers die kern vorm van die literêre auctoritas in die Institusie. Hierin lê trouens die belangrikste onderskeid tussen Institusie en Kategismus soos ons weldra sal aandui. Hierdie onderwerp - auctoritas by Calvyn - is een wat in die lig van die sogenaamde solismes - sola Scriptura, sola fide, sola gratia en soli Deo gloria dringende ondersoek verg om Calvyn se literêre gesagstruktuur bo alle wyfel te stel.

Met hierdie bondige en in vele opsigte ontoereikende karakterisering van die editio princeps moet ons volstaan. Soos hierin aangedui is daar nog baie geleentheid vir literêre ondersoek, maar ons kan ten minste die volgende afleidings maak:

* Die Institusie is tegelyk onderwysing (tradere) en apologie (confessio fidei);

** Dit is 'n disputatio - 'n debat met 'n denkbeeldige Gesprächspartner;

*** Argumentum en ratio is die (retoriese) middels wat in die debat gebruik word;

**** Calvyn se teikengebied is die ,breitesten Massen' wat nog ver$\mathrm{knog}$ is aan die Roomse, Libertynse, Anabaptiste of ander sektes;

***** 'n Kenmerk van die Institusie is dat dit geweldig sterk aansluiting vind by die klassieke erfenis, formeel sowel as in die groot hoeveelheid aanhalings of verwysings na klassieke heidense skrywers.

Vanaf 1536 tot 1559 brei die Institusie weliswaar sowat vyfkeer in volume uit. En hoewel daar ook 'n verskuiwing van doelstelling kom (in die laaste uitgawe is dit primèr gerig daarop om aan die teologiese student leiding te gee) het die Institusie nooit werklik van karakter verander nie. In die voorwoord aan die leser merk Calvyn op dat hy ,hoegenaamd nie die sukses verwag het wat die Here in sy grenslose wysheid daaraan gegee het nie' en hy meld dat hy ,in die eerste uitgawe van die werk die onderwerp grootliks oppervlakkig behandel het' (OC 2.1). Geen wonder dus dat hy nie met die werk tevrede was totdat dit uiteindelik in die 1559-uitgawe 
finale beslag gekry het nie - etsi autem laboris tunc impensi me non poenitebat, numguam tamen mihi satisfeci, donec in hunc ordinem qui nunc proponitur digestum fuit-hoewel ek nie spyt was oor die inspanning wat ek toe aan die werk bestee het nie. was ek tog nooit daarmee tevrede nie totdat dit in hierdie volgorde waarin dit nou aan $u$ voorgesit word verdeel is nie.

Die behandeling van die redes vir en die wyse waarop hierdie uitbreidings in die Institusie geinkorporeer is, vorm nie deel van ons tema nie. Genoegsaam om te meld dat 'n verdiepte Skrifkennis, 'n uitgebreider kennis van die Kerkvaders, 'n konstruktiewe polemiek met teenstanders van die Reformasie (soos die met Sadolet, Pighius, Caroli en Cochlaeus) en preek en leerervaring almal faktore was wat daartoe 'n bydrae gelewer het. Maar vir ons onderwerp is dit in besonder van belang dat daar vanuit die Institusie ook ' $n$ invloed op ander werke van Calvyn waargeneem kan word sodat gesê kan word dat sy opus magnum die fons omnium opusculorum is.

\subsection{Die 1539-uitgawe}

Baie van wat ons hierbo gesê het kan heelhuids net so op die 1539-uitgawe van toepassing gemaak word. Die eerste uitgawe het ses hoofstukke, die 1539-uitgawe sewentien. Die belangrikste prikkel vir hierdie uitbreiding spruit na my mening uit 'n reeks kommentare op die Romeinebrief ${ }^{3}$. Ons het reeds verwys na die brief aan die leser wat vanaf die 1539-uitgawe 'n permanente deel word van die Institusie. Daarin lees ons van die sukses wat op die publikasie van hierdie eersteling gevolg het. Dit word ook bevestig deur 'n brief van die bekende uitgewer Oporinus gedateer 25 Maart 1537 wat nie slegs vir hierdie inligting vir ons van belang is nie, maar ook om die algemene verwarring ten opsigte van die woorde institutio en catechismus te illustreer. Hy merk in die brief naamlik op: De catechismo tuo scias, mi Calvine, magnam esse expectationem; quando eum recognitum denuo editurus sis. Cupiunt hoc plerique et exemplarium antea a nobis excusorum nullum nobis superest amplius, hic saltem Basileae. Francfordiae autem vix quinquaginta adhuc habere nos puto. Ita feceris rem gratissimam et sacrae theologiae studiosis, si editionem aut recognitionem illam tuam matures, et nobis in primis, si in recudanda illa opera mostra uti non dedigneris (OC 5. XLIII, prolegomena). Die werk waarna Catechismo hier verwys is duidelik die Institusie (1536) wat in Basel gepubliseer is. In Basel is daar geen boek meer beskikbaar nie, terwyl daar miskien 50 eksemplare daarvan in Frankfurt nog oor is. Cupiunt hoc plerique - baie mense verlang die werk dringend - gee 'n aanduiding van die inslag wat hierdie werk by die eerste publikasie reeds ervaar het.

Natuurlik verwys plerique hier na Calvyn se teikengebied en ons kan ons met reg die vraag afvra waarom die werk soveel sukses behaal het. Daarvoor kan natuurlik verskeie redes aangevoer word, maar een van die belangrikstes is dat Calvyn in die Institusie praat in die verstaanbare idioom van sy tyd en dit is, of ons dit nou wil aanvaar of nie, die idioom van die Skolastisisme en die Humanisme ( igl Wendel, L'Humanisme, p. 9). 
Die 1539-uitgawe het egter nie spontaan net gegroei om die redes wat hierbo vermeld is nie. Daar is ook brae geslaan tussen hierdie twee en die-voor-die-hand-liggende is die Kategismus van 1538. Laat ons egter eers die Confessio wat om besondere redes hierby ingesluit is bespreek.

4. Die confessio 1538

Oor die aard en die ontwikkeling van konfessionele literatuur wil en kan ek my nie uitspreek nie. Ons het hierin tevore reeds daarvan melding gemaak dat die vervolgingsmilieu waaruit die eerste Institusies gegroei het veroorsaak het dat 'n konfessionele karakter ook daaraan toegevoeg is en dat hierdie konfessionele karakter weerspieël word in ' $n$ apologetiese faset. Dit is 'n verbasende feit dat 'n confessio - 'n be-LY-denis onder sulke omstandighede ontstaan het. Die woord confessio (in die Kategismusuitgawe van 1545 kom ook die woord professio met skynbaar sinonieme betekenis voor, vgl. vraag 363 in die vertaling) ontspring uit die Romeinsregtelike skulderkentenis. Die twee pole in ' $n$ regsgeding waarvolgens die res van die verloop van die geding bepaal word, was trouens confessio of defensio - skulderkenning of verdediging. In die Vroeg Christelike milieu het dit die betekenis van 'n ,erkenning' van Christus (Vgl. Vulgaat Rom. 10.10) gekry. Vanaf Tertullianus en in besonder in die tydperk vanaf 250 tot 312 n.C. - die tydperk van die LY-dende kerk - het dit ook die betekenis van 'n be-LY-denis onder foltering en LY-ding gehad. Dit is ook in hierdie sin waarin die Institusie ' $n$ belydenis van die geloof is - protestante ly immers vir hulle erkenning van die vera doctrina. Calvyn poog dus om die iniquitas van die owerheid aan te toon deur ' $n$ weergawe van die protestantse erkenning onder lyding.

Hoewel Calvyn die insluiting van die confessio fidei by 'n uitgawe van die Kategismus op ander gronde regverdig kan dit ons nie ontgaan dat hy en Farel onder die las van beswaddering en laster gebuk gegaan het en dat hulle daarom genoodsaak is om belydenis van hulle geloof te doen nie. In die praefatio van die werk vermeld Calvyn dat 'n persoonlike beswadderingsveldtog (deur Caroli) op sy oortuiging in verband met die Triniteit gedoen is en dat dit die rede vir die insluiting van die confessio fidei by die Kategismus was. Hy skryf dat hy geen belang daarby het om in die Kategismus sy persoonlike voor- of afkeure in te voeg nie (nostra), maar dat hy slegs die beginsels wat hy uit die Skrif put daarby wil inkorporeer (e puro verbo Dei sumpta).

Die belangrikheid van hierdie confessio fidei word in die uiteensetting wat hy daarop maak verduidelik. Nadat hy die opmerking gemaak het dat hy in die een wese (essentia) van God die Drieeenheid van sy Persone (persomarum trinitatem) bely, voeg hy daar by: Iam vero confessionem, solenni iureiurando ab universo populo editam, non sine ratione adiungendam curavimus (OC 5.318, 319) maar ek het nou die belydenis wat deur ons hele volk onder heilige eed uitgevaardig is, nie sonder rede hier by laat voeg nie.' Die rede is dat hy daardeur verseker is van die beskerming van die senatus genevensis teen beswadderingsveldtogte soos die van Caroli en van 
mense wat poog om in enige opsig verdenking teen hom te saai. Die woorde iureiurando solenni spruit uit die eed wat die inwoners van Genève by hierdie confessio fidei moes sweer (plebs decuriatim convocata.... in confessionem iurarent.)

Terloops wil ons die opmerking maak dat Calvyn nie daarop aanspraak maak dat hy die opsteller van die confessio fidei is nie. Hy meld bloot dat ' $n$ belydenisformulier aan die senatus genevensis voorgelê is - oblata confessionis formula. Die feit dat die hele uiteensetting hierbo in die meervoud gestel is mag wel aandui dat Farel ook by die tumultus betrek is. Die struktuur van die confessio verskil voorts geheel en al van die van die Institusie en die Kategismus. ' $n$ Voorbeeld van die inhoud hiervan tesame met die vertaling daarvan kom op p. 70 van die vertaling van die Kategismus voor. (Vgl. OC 5. 355).

In die lig hiervan mag dit wel daarop dui dat Farel 'n aandeel of selfs die leeueaandeel in die opstelling hiervan gehad het. Die onderwerp is egter verder nie vir ons van belang nie en ons laat die interessante vraagstuk daar.

5. Die Catechismus Genevensis.

Volgens die opstellers van die Corpus Reformatorum het daar nie minder nie as vier uitgawes van die Catechismus Genevensis binne sowat nege jaar vanaf 1536 tot 1545 verskyn.

\subsection{Die Catechismus - 1936.}

Volgens dieselfde opstellers het die eerste uitgawe van Calvyn se Kategismus reeds in 1536 verskyn. Hulle lei dit by gebrek aan 'n teks af uit die titel van die 1538-uitgawe wat soos volg lui: Catechismus sive christianae religionis institutio communibus renatae nuper in Euangelio Genevensis Ecclesiae suffragiis recepta et vulgari quidem prius idiomate, unuc vero Latine etiam quo de fidei illius synceritate passim aliis etiam ecclesiis constet, in lucem edita Ioanne Calvino autore. (OC 6.XL1, prolegomena). In vertaling lui dit: 'n Kategismus of institusie van die Christelike godsdiens wat in 'n algemene stemming van die Kerk van Genève wat onlangs in die evangelie wedergebore is, aanvaar is, en eers in die algemene spreektaal, maar nou ook in Latyn gepubliseer is sodat die opregtheid van die geloof van die kerk oral aan ander kerke duidelik mag wees, deur die skrywer Johannes Calvyn.'

$\mathrm{Na}$ aanleiding van die opmerking vulgari quidem prius idiomate en opmerkings van Colladon en Beza in die Vita Calvini wat in laasgenoemde lui: tunc edita est a Calvino christianae doctrinae quaedam veluti formula, vixdum emergenti papatus sordibus genevensi ecclesiae accomodata. Addidit etiam Catechismum non illum in quaestiones et responsiones distributum quem nunc habemus, sed alium multo breviorem, praecipua religionis capita complexum toe is ' $n$ formulier van die christelike leer deur Calvyn uitgegee toe hy nouliks uit die gemors van die pousdom tevoorskyn getree het, en dit is aan die kerk van Genève beskikbaar gestel. Daarby het hy ook 'n Kategismus gevoeg, nie die een wat ons nou het wat in vraag en antwoord verdeel is nie, maar ' $n$ ander een wat baie bondiger is 
en die belangrikste hoofpunte van ons godsdiens insluit. (Vgl. die Vita Calvini in Santandreanus se 1597 uitgawe p. 5).

Die opstellers merk verder op:

- Dat die werk in 1536 of vroeg in 1537 in Frans geskrywe en gepubliseer is:

** Dat dit by die geloofsformulier gevoeg is wat nooit tevore in druk verskyn het nie;

*** Dat die plek van oorsprong onbekend is en

**** Dat 'n eksemplaar hiervan nooit gevind kon word nie omdat dit in die hande van kinders verslyt het en verwoes is ,soos wat gewoonlik maar met sulke werke gebeur (puerorum nimirum manibus triti et lacerati ut in his scholasicis pagellis fieri solet); en dat die feit dat Calvyn dit met 'n tweede vervang het, die eerste in vergetelheid laat verval het.

Met groot respek vir die opstellers lyk al die argumente vir my te deursigtig. Die kosbare kleinnood en een van Calvyn se belangrikste werke is tog deur die Senatus Genevensis goedgekeur en nie net deur kinders gebruik nie. Die 1536-uitgawe van die Institusie en ook daaropvolgende uitgawes het tog nie verdwyn bloot omdat dit met hersiene en verbeterde uitgawes vervang is nie!

Die woorde vulgari quidem prius idiomate, nunc vero Latine in lucem edita dui eerder aan dat die werk oorspronklik in Latyn geskrywe is, toe in Frans vertaal eerste in die taal gepubliseer en later, as gevolg van ' $n$ besondere behoefte daaraan is ook die oorspronklike Latynse teks gepubliseer. Die feit dat die 1538-uitgawe blyke gee van 'n woordelikse oorskrywe van sekere dele van die Institusie is die duidelikste bewys daarvan. Dit is tog onwaarskynlik dat 'n Franse uitgawe weer woordeliks terug vertaal kan word in presies die woorde wat in die Institusie staan!

Van 't Veer maak die opmerking dat Bordier die Franse uitgawe van 1538 wel onder die boeke van Dupuy gevind het en dat Rilliet en Dufour dit in 1878 met historiese en bibliografiese kommentaar uitgegee het (Van 't Veer, p. 24, n. 6). 'n Soortgelyke fonds kon nooit van die 1536-uitgawe gemaak word nie. Wendel wie se oordeel ek in sake soos hierdie hoog waardeer, bespreek die vraagstuk nie, maar hy stel markant sy standpunt: ,La plus anciénne édition francaise qui ait été retrouvée est de 1545 - die oudste Franse uitgawe wat gevind is, is die van 1545 . Van 't Veer laat die vraagstuk oop hoewel hy neig om met Rilliet en Dufour saam te stem ,om de Fransche redactie als de oorspronklijke te zien' (p. 26). Peter (Regards, p. 175) plaas Calvyn se Kategismus in die milieu waaruit dit gespruit het en meld in verband daarmee elementêre beginnersboekies uit Roomse sowel as Protestantse kamp. Daaronder val onder andere uitgawes van die Rooms Katolieke Gabriel Pomar in 1530 en 'n ander van Wiegend Koeln in 1532. 'n Uitgawe wat vir ons van groot belang is as vcorloper van Calvyn se Kategismus en een wat seker ook invloed daarop uitgeoefen het, is die van sy neef, Robertus Olivetanus van 1533. Die titel daarvan is: L'Instruction des enfants, contenant la maniere de prononcer et escrire en francoys. Dit het ingesluit: L'oraison de lesu Christ: Les articles de 
la foy: les dix commandemens. Dit is inderwaarheid 'n antwoord op die twee Roomse uitgawes hierbo en die feit dat dit tot in 1537 - l'annee même de la parution du premier Catechisme de Calvin nie minder as 10 uitgawes nie beleef het, spreek boekdele vir die agting wat die werk in Genève geniet het.

Die algemene opvatting is dat Bucer of Luther se Kategismus as voorbeeld vir Calvyn gedien het by die opstelling van sy Kategismus. Dit is 'n uitgangspunt wat in die lig van Calvyn se noue verbintenis met die skrywer en die gebruik van die werk in Genève hersien moet word. Die uiteensetting hierbo is egter vir ons van groter belang daarvoor dat Peter nie ' $n$ aanduiding gee van enige uitgawe voor 1537 - die jaar waarin Calvyn volgens hom besig was met die voorbereiding van die 1538-uitgawe - nie.

Laat ons egter hiermee volstaan. Dit is 'n vraagstuk waaroor die laaste woord nog nie gespreek is nie en terwyl die teks nie tot ons beskikking is nie, is daar niks wat ons daaruit verder vir ons bespreking kan put nie.

5.2. Die Catechismus 1538 (OC 5.XLI, prolegomena en teks 5.323362 ).

Ons moes noodwendig heelwat inligting in verband met hierdie uitgawe hierbo verstrek en herhaal dit nie hier nie. Die 1538Kategismus bly steeds een van die belangrikste bronne vir die bestudering van Calvyn se konstruktiewe vorderende skrywersaktiwiteit. Dit gryp naamlik eerstens terug op die editio princeps en neem groot dele daarvan woordeliks oor - soveel as die helfte van hierdie Kategismus is ' $n$ woordelikse oorskrywe van die eerste uitgawe van die Institusie! In die tweede plek is die Kategismus ook 'n projeksie van die inhoud van die 1539-Institusie. In die opsig gee dit trouens duidelik blyke daarvan dat Calvyn wegbeweeg van die Lutheraanse wettisisme en dat hy op soek is na 'n sisteem om dit te vervang. Maar meer nog is hierdie Kategismus verbasend daarin dat dit nie in vraag en antwoord onderverdeel is nie - non in quaestiones et responsiones distributum - maar in kategories dogmatiese stelling verdeel is. 'n Voorbeeld hiervan tesame met die vertaling daarvan (in casu die uiteensetting in verband met die vrye oordeel) vind $u$ op $p .70$ van die vertaling.

Dit is vir ons onderwerp egter van groter belang om die verhouding tussen hierdie Kategismus en die twee uitgawes van die Institusie wat dit oorbrug vas te stel. Met die oog hierop word 'n skematiese voorstelling hierby ingevoeg wat hierdie verhouding duidelik stel.

INSTITUTIO 1536

1. De lege quod Decalogi explicationem continet - die wet wat ook 'n verduideliking van die Dekaloog insluit.

1. De fide ubi et symbolum quod Apostolicum vocant explicatur - die geloof waar ook 'n uiteensetting gegee word van die apostoliese teken (geloofsbelydenis).

3. De oratione ubi et oratio dominica enarratur-oor die gebed waar ook die gebed van die Here weergegee word. 
4. De sacramentis ubi de baptismo et coena Domini-die sakramente waar ook oor die doop en die eetmaal van die Here gehandel word.

5. Quo sacramenta non esse quinque reliqua quae pro sacramentis vulgo habita sunt - dat die 5 oorblywendes wat oor die algemeen as sakramente beskou is, nie sakramente is nie.

6. De libertate christiana, potestate ecclesiastica, politica administratione.

\section{CATECHISMUS 1538}

1. Omnes homines ad religionem esse natos. (Dat alle mense vir die godsdiens gebore is).

2. Quid inter falsam ac veram religionem intersit - die verskil tussen ware en valse godsdiens.

3. Quid de Deo nobis cognoscendum - wat ons van God moet leer.

4. Quid de homine - en wat van die mens.

5. De libero arbitrio - vrye oordeel.

6. De peccato et morte - oor sonde en dood.

7. Quomodo in salutem ac vitam restituamum - die wyse waarop ons in saligheid en in die lewe herstel word.

* De lege Domini - die wet van die Here.

8.1. Legis summa - die som van die wet.

8.2. Quid ex sola lege ad nos redeat - die voordeel wat ons slegs uit die wet put.

8.3. Legem gradum esse ad Christum - die wet is 'n trap na Christus.

9. De fide-die geloof.

9.1. Christum fide a nobis apprehendi - Christus word deur die geloof aangeneem.

9.2. De electione et praedestinatione - verkiesing en predestinasie.

9.3. Quid sit vera fides - wat ware geloof is.

9.4. Fides donum Dei-geloof is 'n gawe Gods.

9.5. In Christo iustificamur in fidem - ons word in Christus geregverdig in die geloof.

9.6. Per fidem sanctificamur in legis oboedientiam - deur die geloof word ons geheilig tot gehoorsaamheid van die wet.

9.7. De poenitentia et regeneratione-berou en wedergeboorte.

9.8. Quomodo bonorum operum et fidei iustitia simul conveniant - die harmonie tussen goeie werke en geloofsgeregtigheid.

9.9. Symbolum fidei-geloofsbelydenis.

9.10. Quid sit spes - die betekenis van hoop.

10. De oratione - oor die gebed.

10.1. Quid in oratione spectandum - wat in die gebed in aanmerking geneem moet word. 
10.2. Orationis Dominicae enarratio - 'n weergawe van die gebed van die Here.

10.3. Orandi perseverantia - volharding in die gebed.

11. De sacramentis - die sakramente.

11.1. Quid sacramentum sit - wat sakramente is.

11.2. De baptismo

11.3. De coena Domini

12.1. De ecclesiae pastoribus et eorum potestate - herders van die kerk en hulle bevoegdheid.

12.2. De traditionibus humanis - tradisie.

12.3. De excommunicatione.

12.4. De magistratu.

INSTITUTIO 1539

1. De cognitione Dei - die kennis van God.

2. De cognitione hominis - kennis van die mens.

et lebiro arbitrio - vrye oordeel.

3. De lege (sequitur expositio mandatorum-Die wet en 'n uiteensetting van die gebooie.

4. De fide ubi et symbolum quod apostolicum vocant explicatur - die geloof waar ook 'n uiteensetting gegee word van die apostoliese teken (geloofsbelydenis).

5. De poenitentia - berou.

6. De iustificatione fedei et meritis operum - regverdigmaking van die geloof en verdienste van ons werke.

7. De similitudine ac differentia veteris et novi Testamentidie ooreenkoms en verskil tussen Ou en Nuwe Testament.

8. De praedestinatione et providentia - predestinasie en voorsienigheid.

9. De oratione - oor die gebed.

10. De sacramentis - die sakramente.

11. De baptismo.

12. De coena Domini.

13. De libertate christiana.

14. De potestate ecclesiastica.

15. De politica administratione.

16. De quinque falso nominatis sacramentis.

17. De vita hominis christiani.

Uit hierdie skematiese voorstelling kan ons die volgende afleidings maak:

* In die eerste plek is dit duidelik dat die 1538-Kategismus die brug vorm tussen die twee uitgawes van die Institusie;

* In die tweede plek is die weglatings van inligting in die Institusie uit die Kategismus hoogs insiggewend ten opsigte van die aard van die Kategismus. Opvallend is die weglating van die inhoud van die vyfde hoofstuk van die 1536-uitgawe (hoofstuk 16 van 1539); dit is in besonder hierdie hoofstukke wat na my mening die apologetiese inhoud dra. Die weglating van die hoofstukke wat ook as die pars polemica beskrywe kan word, gee duidelik blyke van die besondere karakter wat Calvyn van meet af aan die Kategismus gegee het. 
*** Dit is voorts duidelik dat Calvyn naarstig op soek is na die ideale sisteem vir die Institusie. Hoofstukke 5, 6 en 8 stem byvoorbeeld nie ooreen met die plek wat dit in die Kategismus ingeneem het nie.

**** Ons moet in aanmerking neem dat die Institusie vanaf 1536 tot 1539 verdriedubbel, terwyl die Kategismus 'n ooreenstem. mende inkorting toon. Calvyn stagneer dus nie in sy denke en soeke na 'n ideale sisteem nie, maar hy maak ook nood. saaklike toevoegings, soos hoofstukke 7 en 17 getuig.

Van 't Veer het enkele verskille en ooreenkomste tussen die 1538-uitgawe en die Rilliet en Dufour-teks aangedui. Ons vind dit nie nodig om dit hier te herhaal nie. (Van 't Veer, p. 43 e.v.).

Genoegsaam om samevattend daarop te wys dat Calvyn vanaf sy eersteling Kategismus poog om die polemiese inhoud uit die Kategismus weg te neem. Dit is egter nie 'n vereenvoudiging van die 1536-Institusie nie, maar bloot 'n verkorting daarvan.

5.3. Die 1545-uitgawe van die Catechismus

Tussen 1538 en 1545 het daar verskeie uitgawes van die Kategismus verskyn (vgl. OC 6.XIII, prolegomenta). Dit is egter in besonder die 1945-uitgawe wat ons interesseer en daarom laat ons ' $n$ bespreking van die ander agterweë.

Uit die praefatio hiervan blyk dit dat Calvyn nie tevrede was met die vorige uitgawes nie. Hy noem die eerste uitgawe dan 'n brevis religionis summa sub Catechismi nomine. Hy verkies nie alleen die 1545-uitgawe nie, maar hy wil ook verhoed dat daar weer 'n uitgawe van die 1538-Kategismus gepubliseer word. Hy is dus deeglik bewus van die gebreke van hierdie eersteling.

Maar dit is nie alleen om hierdie rede dat hy dit nodig vind om 'n nuwe uitgawe die lig te laat sien nie. Verskeie ander redes noop hom trouens daartoe om 'n nuwe uitgawe te publiseer. Hy noem onder andere die volgende:

* 'n eenvormige kategismusformulier is gewens (unam ecclesiis omnibus esse catechismi fornam optandum est);

** 'n eenvormige Kategismus sal die onderlinge band tussen kerke verstewig (ecclesiae reliquias scriptis nostris colligamus);

*** hy wil met die nuwe uitgawe voldoen aan 'n versoek uit verskeie oorde dat hy so 'n kategismus moet opstel; die groot hoeveelheid vertalings wat van die werk gemaak is - ook in Grieks en Hebreeus - getuig van die behoefte aan so 'n Kategismus.

**** hy wil voorts aan ander kerke 'n voorbeeld van die optrede in Genève bied omdat hy Genève as die bastion teen die Roomse kerk sien.

Wat is nou die belangrikste veranderinge wat Calvyn aanbring? Die titel van hierdie werk gee klaar 'n aanduiding daarvan. Dit lui: Catechismus ecclesiae Genevensis hoc est formula erudiendi pueros in doctrina Christi. As ons dit met die titel van die 1538 . uitgawe vergelyk is die eerste opvallende weglating die woord Institutio. Dit is van die grootste belang omdat daar nou skeiding tussen breë en besondere onderwys in Calvyn se denke gekom het. 
Die byvoeging van die woorde formula erudiendi pueros dui trouens aan dat Calvyn bewus is van 'n besondere teikengebied-die van die (verbonds-) kind. Die uitgangspunt noop hom om ook formeelinhoudelike veranderings aan te bring. Daarom is die werk in quaestiones et responsiones distributum. Die kategories dogmatiese stelling mak daarin plek vir die vraag-dus 'n verskuiwing van die antitetiese na die tetiese. In die Franse uitgawe word die werk verdeel in 55 Sondae en in die Articles sur le gouvernement de l'Eglise wat reeds op 10 Januarie 1537 aanvaar is, word bepaal dat ouers hulle kinders elke Sondagmiddag vir die onderwysing in die doctrina christi na die kerk moes bring. By voltooiing van hierdie Kategismus moes die kind voor die gemeente op sekere vrae antwoord voordat hy toegelaat is om aan die Nagmaal deel te neem. Ook vir hierdie vrae is daar vanaf 1551 'n vasgestelde formulier opgestel bekend as La manier d'interrogeur les enfans qu'on veut recevoir a la cene de nostre Seigneur lesus Christ. (OC 6.147 e.v.). Ook daar neem die minister - die bedienaar van die Woord die inisiatief en die puer antwoord op die vrae.

Die werk is gerig en opgedra aan die predikante van Oos-Friesland wat waarskynlik ook die versoek aan Calvyn gerig het.

Inhoudelik is die werk nie in hoofstukke nie, maar in hoofpunte verdeel. Dit sien soos volg daar uit:

* Die eerste handel oor die geloof (vraag 1-131);

* Die tweede oor die wet (vraag 132-232);

*** Die derde oor die gebed (vraag 233-296);

**** die vierde oor die Woord van God (vraag 297-309);

**** die vyfde oor die sakramente (vraag 310-374).

Hierop volg daar voorbeelde van verskeie gebede wat almal daarop gemik is om aan die kind leiding te gee oor die wyse waarop hy moet bid.

Daar kan weinig twyfel daaroor bestaan dat Calvyn in sy doelstellinge geslaag het. Sy Kategismus was trouens een van die belangrikste bronne by die opstel van die Heidelbergse Kategismus. Wendel (Sources, p. 54) sien dit so: ,Des le XVI siècle, on en fit nombreuses traductions, et il servit de base du Catechisme de Heidelberg qui devint, comme l'on sait, le catechisme-type des Eglises réformées.' Maar ten spyte hiervan moet dit ook helder klaar wees dat dit die Heidelberger nooit kan vervang nie en nie bloot om die logiese indeling daarvan nie, maar in besonder om die toonverskil tussen die twee.

Dit doen egter geen afbreuk aan die belangrike plek wat die Kategismus in die loop van die historiese ontwikkeling van die kategismus inneem nie. In die Wezelsche Artikelen van 1568 (Hoofstuk 111, De catechismo, 2) word die belangrikheid daarvan beklemtoon: Catechismi autem formulam in ecclesiis quidem Gallicanis, Genevensem, in Teutonicis vero Heidelbergensem, potissimum sequendam ducimus: quam tamen usque ad futuram Synodum liberam relinquimus - na ons mening moet die Kategismusformulier van Genève in die Franse kerke, en die Heidelbergse in die Dietse kerke gevolg word; tog laat ons die vraagstuk oop vir 'n toekomstige sinote. 
In die Acta van die Emdense sinode kom 'n soortgelyke besluit voor (1571, Art. 5) met die byvoeging dat kerke ook van ander Kategismusformuliere gebruik kan maak mits hulle verbo Dei consentanea is. Op 16 Junie 1574 besluit die Sinode van Dordt (Art. 2): ,De versamelinghe heeft besloten dat men eenerleij Catechismum in alle Kercken der Provincie houden sal. Ten anderden dat dit sal wesen de Heidelbergsche (sic!) Catechismus.' (vgl. Rutgers, p. 134). Dit gee na my mening die wel en die weë van Calvyn se Kategismus voldoende weer.

Dit is tog vreemd dat Calvyn die Kategismus in Latyn opgestel het. Hy pleit trouens daarvoor dat die woordverkondiging in die moedertaal moet wees en hy wys in die 1536-Institusie reeds daarop dat dit sinneloos is om tot God te bid in woorde wat vir die een wat bid onverstaanbaar is. Moedertaalonderwys is sekerlik die vorm waarin hy ook kategetiese onderrig beplan het. Die vertaling van die Catechismus getuig ondubbelsinnig daarvan dat hy hom ook daarvoor beywer het. Uit die ervaring weet ons watter worsteling studente moet deurmaak om maar net die grondbeginsels van Latyn te bemeester en te oordeel na Quintilianus (Inst. Orat. 1.12.9) is die probleem al eeue oud. Hy sê naamlik noviciis nostris per quot annos sermo Latinus pugnat - hoe lank worstel Latyn nie met nuwelinge nie.

Calvyn verduidelik tog uitdruklik waarom hy sy Kategismus in Latyn geskrywe het ten spyte van teenstand uit verskeie oorde. Die redes wat hy daarvoor aanvoer is:

* Latyn is na sy mening 'n belangrike kommunikasiemedium tussen kerke;

** dit is 'n bastion teen die barbaredom wat dreig om oor die wêreld te vloei;

*** dit bevorder die consensu tussen kerke;

**** dit bied vir die nageslag uit alle volke 'n bron waaruit hulle kan put.

Ons kan die feit dat Latyn tot 1793 die amptelike akademiese taal was nie misken of wegwens nie. Daarby kan ons die feit dat die Westerse kerkgeskiedenis en die ontwikkeling op haas elke gebied van die kerklike lewe in Latyn geskrywe is nie wegargumenteer nie. Uit eie ervaring weet ons dat sowat $90 \%$ van alle literatuur in verband met die Kerkvaders uit Roomse kamp afkomstig is. Van Protestantse kant word weinig as teenprestasie gelewer. Van die sowat 400 volumes van die belangrikste bron in verband met die Patrologie (Migne) besit ons plaaslik 29 volumes - nie genoegsaam om eers te dink daaraan om die massa verwysings in Calvyn se werke op te volg nie!

Op internasionale Calvynkongresse het dit gebeur dat die bydraes van Rooms-Katolieke navorsers soos Luchesius Smuts en Ganoczy met groot akklamasie verwelkom is en die voorsitter van een van die vergaderings kon opmerk: Wenn ich recht sehe, befassen sich die katholische Forscher im Augenblick mit keinem Reformator so intensiv wie mit Calvin!' (Neuser, Calvinus ecclesiae doctor, p. 16). Mag ons daarvan bewaar bly dat ons kosbare erfgoed oorgaan in 
die hande van die mense teen wie die Reformasie ten aanvange gerig was.

Dit is tog duidelik dat ons die stroom van literatuur uit Roomse kamp slegs kan teengaan as ons ook die manne lewer wat die opleiding en bekwaamheid het om 'n beter teenprestasie te lewer. Ek wil u daarom ernstig versoek om teologiese studente aan te moedig om Latyn te neem om hulle sodoende voor te berei om die werk voort te sit. Voorts verstout ek my, geagte Voorsitter, om te versoek dat van kerkweë daadwerklik planne bedink en koppe bymekaar gesit moet word om die noodsaaklike bronne vir die bestudering van ons Christelike erfenins te bekom. Miskien is dit te vergesog om in verband daarmee ook die begeerte uit te spreek dat 'n navorsingsfonds so gou doenlik in die lewe geroep word om die navorsing wat in belang is van ons kerk te stimuleer en te finansier.

\section{Samevattend}

Om terug te keer tot ons onderwerp: samevattend kan die resultate van ons ondersoek soos volg weergegee word:

* eerstens is dit duidelik dat beide Institusie en Kategismus 'n onderliggende didaktiese infrastruktuur het; in albei gevalle dui Calvyn aan dat hy differensiërend te werk wil gaan; in die geval van die Institusie wil hy grondbeginsels van die vera doctrina aan simpliciores oordra. In die geval van die Institusie is die kernwoord tradere. In die geval van die Kategismus beoog hy om kinders op te voed. Die kernwoord hier is erudire.

* Die teikengebied verskil dus - in die geval van die Institusie is dit volwasse-onderwys, terwyl die verbondsjeug die leersubjek in die Kategismus is.

*** Ook in die vorming van sy Kategismus groei Calvyn se denke totdat hy bevredig is met die vorm waarin dit gegiet word. In die geval is die skeiding tussen Institusie en Kategismus in sy denke die begin van twee selfstandige onderwysmedia;

**** ten slotte het Kategismus nie die middele van die retoriek en die auctoritas van paganistiese skrywers nodig nie; dit is gebou suiwer op die Woord van God alleen - sola Scriptura!

Gelewer voor die GTV, Potchefstroom, 27 April 1981.

\section{BRONNELYS:}

1. Corpus Reformatorum, (OC: Opera Calvini) ediderunt Baum, Cunitz en Reuss, Brunsvigae, 1861 e.v.

2. Tractatus Theologici Omnes in unum volumen certis classibus congesti, Genvae, apud Santandreanum, anno MDXCVII.

3. Christianae religionis institutio, Basileae, MDXXXVI.

4. Ibid, Argentorati per Rihelium, MDXXXIX.

5. Bouwmeester, G.: Caspar Olevianus en zijn Reformatoriese arbeid, Willem de Zwijgerstichting, 'sGravenhage, 1954.

6. Id.: Zacharias Ursinus en de Heidelbergse Catechismus, 'sGravenhage, 1954.

7. Neuser, W. H.: Calvinus Theologus, Neukirchner Verlag, Neukirchner-Vluyn, 
1976

Calvinus ecclesiae doctor, Kok, Kampen, 1978.

8 Rutgers, F. L.: Acta van de Nederlandsche Synoden der zestiende eeuw, 'sGravenhage, Nijhoff, 1889.

9. Todd, W. N.: The function of the patristic writings in the thought of John Calvin, Ann Arbor, Michigan, 1970.

10. Van 't Veer, M. B.: Catechese en catechetische stof bij Calvijn, Kok, Kampen, 1942.

11. Wendel, F : Calvin: Sources et évolution de sa pensée religieuse, Presses Universitaires de France, Paris, 1950.

Calvin et l'humanisme, Presses Universitaires de France, Parys, 1976

12. Mehl, R., (Ed.): Regards contemporains sur Jean Calvin, Actes du colloqui Calvin Strasbourg, 1964, Presses Universitaires de France, Parys, 1965.

13. Wiley, D.: Calvin's doctrine of predestination: his principal soteriological and polemical doctrine, Ann Arbor, Michigan, 1971.

\section{VERWYSINGS}

1. Vgl. Gemser, Hebreeuse Grammatika, van Schaik, Pta, 1953: Luther se adres aan die Burgemeesters en raadshere van allerlei stede in Duitse lande, 1524, dui hierdie verband met 'n uiteensetting van die verhouding tussen die tale en die Evangelie uitmuntend aan: ,So lief as wat vir ons almal die Evangelie is, laat ons net so vas aan die tale hou.... En laat dit ons gesê wees: dat ons die Evangelie nie goed sal behou sonder die tale nie. Die tale is die skede waarin die mes van die Evangelie steek. Hulle is die juweelkassie waarin mens die kleinnood dra. Hulle is die beker waarin mens hierdie drank kry. Hulle is die provisiekamer waarin hierdie spyse le. Hulle is die mandjies waarin hierdie brood en visse en brokke gekry word. Daarom is dit seker: waar die tale nie bly nie, daar moet ook die Evangelie ten slotte ondergaan.'

2. Vgl. Wendel, p. 79 wat volledig uit Imbert de la Tour aanhaal

3. Tussen 1530 en 1540 het verskeie kommentare op die Romeinebrief verskyn. 